\title{
THE EFFECT OF PLANT PRUNING ON THE LIGHT CONDITIONS AND VEGETATIVE DEVELOPMENT OF EGGPLANT (SOLANUM MELONGENA L.) IN GREENHOUSE CULTIVATION
}

\author{
Anna Magdalena AMBROSZCZYK, Stanisław CEBULA, Agnieszka SĘKARA \\ Department of Vegetable Crops, Agricultural University in Krakow \\ 29 Listopada 54, 31-425 Kraków, Poland
}

Received: February 4, 2008; Accepted: May 26, 2008

\begin{abstract}
Summary
The aim of the present investigations was to find the relations between pruning methods and chosen parameters of vegetative eggplant development in greenhouse conditions. The plant shape modifies the photosynthetically active radiation (PAR) conditions in the plant profile. Independence between different pruning methods and vegetative plant development particularly leaves characteristics as well as pigments and photosynthesis products content in leaves was stated. The investigations were carried out in 1999-2001 in the experimental greenhouse of Agricultural University in Kraków, Poland. Eggplant of Tania $F_{1}$ hybrid was used in the early spring-summer production in a heated greenhouse. The following pruning systems were applied: pruning to one shoot with leaving on every node 2 fruit sets and 1, 2 or 3 leaves, and pruning to two shoots with leaving on every node 1 fruit set and 1, 2 or 3 leaves. With the introduction of a greater number of leaves and fruit sets on eggplant shoots irradiation in plant profile was reduced. The value of leaf area index (LAI) depended on the way of pruning. Chemical composition of leaves was slightly dependent on the method of pruning only in the case of assimilation products, i.e. reducing sugar and starch. Improvement of photosynthesis efficiency of intensively pruned eggplants was achieved by the increase of single leaf area and thickness of leaf mesophyll tissues without the increase of the level of assimilative pigments per plant mass unit.
\end{abstract}

key words: Solanum melongena, aubergine, pruning, vegetative growth, PAR, leaf development, leaf parameters

\section{INTRODUCTION}

Eggplant $F_{1}$ hybrids for glasshouse production are characterized by high growth rate and high solar radiation requirements. The topography of the plant profile creates a specific phytoclimate for glasshouse cultivation (Czarnowski \& Cebula 1996, 1998, 1999). Usually, upper eggplant leaves receive high levels of

Corresponding author:

e-mail: asekara@ogr.ar.krakow.pl

(C) Copyright by RIVC 
the solar radiation, mainly in photosynthetically active radiation (PAR) range. Bottom leaves often receive insufficient PAR doses. A popular technique suggested for eggplant cultivation is stem, leaves, and flowers pruning for proper forming of plant shoots. The method of pruning is determined by the cultivar, plant spacing, time and conditions of growing (Cebula 1996).

Czarnowski \& Cebula (1999) found that spectral transmittance of solar radiation through eggplant canopy depends on the value of leaf area index (LAI). A single eggplant leaf revealed low reflectance, high absorptance, and low transmittance in PAR range. In the near infrared the leaves revealed considerable reflectance, weak absorptance, and high transmittance. This protects the leaves from overheating and inhibition of photosynthesis.

Stem pruning is a growing technique generally used for protected cultivation. The role of pruning in eggplant cultivation and historical review of pruning practices were demonstrated by Pessarakli \& Dris (2003). Last experiments on seven $F_{1}$ eggplant hybrids suggest pruning to two or three shoots (Paksoy \& Akilli 1994). Both pruning types increased the plant length and the first quality fruit yield, and decreased the second class and waste fruits in all cultivars. Eşiyok \& Eser (1998) used Karam $F_{1}$ and Solara $F_{1}$ hybrids to determine the effect of pruning to three and four shoots on yield and earliness of eggplant. Ambroszczyk \& Cebula (2003) pruned Tania $F_{1}$ hybrid to one or two shoots. The authors determined that pruning had a positive effect on irradiation on PAR range in eggplant profile. The significant increase of the fruit total yield was obtained with the introduction of the greater height of the second shoot. To optimizing the proportions between vegetative and generative development of eggplant Cebula (1996) and Cebula \& Ambroszczyk (2000) recommended the technique of pruning to one, two or three shoots together with the leaves and fruit sets cutting.

The aim of the present work was to find the relations between pruning methods and chosen parameters of vegetative eggplant development in greenhouse conditions. The characterized parameters include PAR radiation, leaf area, shape, and thickness, LAI, LAR, LFR, and LAFR indices, dry matter, pigments, sugar, and starch levels in leaves with reference to different ways of pruning.

\section{MATERIALS AND METHODS}

The experiments were conducted in 1999-2001 in a greenhouse of the Agricultural University in Kraków, Poland. The eggplant (Solanum melongena L.) Tania $F_{1}$ hybrid (Syngenta Seeds) was used. Tania $F_{1}$ is characterized by medium-strong growth, high yielding, and oval, purple-black fruits. It is particularly suitable for greenhouse cultivation.

Seeds were sown in boxes filled with peat substrate and placed in a controlled environment: temperature $27 \pm 1^{\circ} \mathrm{C}$ and $\mathrm{RH} 80 \%$. After emergences temperature was maintained at $26 \pm 2^{\circ} \mathrm{C}$ (day) and $21 \pm 1^{\circ} \mathrm{C}$ (night), $\mathrm{RH}$ at $80 \%$, and a supplemental lighting was provided between $3-10 \mathrm{p} . \mathrm{m}$. When the first true leaf was expanding uniform seedlings were pricked out into plastic pots $\varnothing 10 \mathrm{~cm}$, 
filled with peat based substrate. Uniform transplants with 5-6 leaves were finally transplanted into $13 \mathrm{dm}^{-3}$ plastic containers, filled with peat based substrate. The containers were placed directly on the soil surface in a spacing $80 \times 30$ $\mathrm{cm}$. The experimental unit was a plot of a $2.4 \mathrm{~m}^{2}$ surface (10 plants, i.e. 40 plants per treatment). Plants were leaded with strings tied to transversal wires $2.5 \mathrm{~m}$ above the ground. Fertilizer application rate was based on typical recommendations for greenhouse eggplant growing. The fertility status of the substrate was determined by monthly soil analysis. The frequency and duration of fertilization were varied according to the season as well as plant and soil status. Plants were transplanted 16 March 1999, 23 February 2000, and 06 March 2001. The air temperature in the greenhouse was maintained at $26 \pm 2^{\circ} \mathrm{C}$ during the day and $19 \pm 1{ }^{\circ} \mathrm{C}$ during the night, and $\mathrm{RH}$ at $80 \%$. Fruits were harvested once a week, after reaching size and colour sufficient for marketing, from 01 June to 07 September 1999, 31 May to 11 September 2000, and 31 May to 11 September 2001.

The treatments were arranged in a randomized block design in four replications. The following experimental units were compared:

1. Pruning to one shoot with leaving on every node: a) 2 fruit sets and 1 leaf, b) 2 fruit sets and 2 leaves, c) 2 fruit sets and 3 leaves. In this experimental unit two fruit sets were left in each node: one on the main shoot and one on the side shoot. The side shoots were pruned after one (a), two (b) and three (c) leaves.

2. Pruning to two shoots with leaving on every node: a) 1 fruit set and 1 leaf, b) 1 fruit set and 2 leaves, c) 1 fruit set and 3 leaves. In this unit one fruit set was left in each node on the main shoot. The side shoots were pruned after one (a), two (b) and three (c) leaves.

Photosynthetically active radiation (PAR) was measured at 12 a.m. - 1 p.m. on sunny days, using a linear quantum sensor LI-COR above the plants $(100 \%)$, and at three levels of plant profile: the main embranchment, fruiting, and flowering.

The leaves sampled from the primary shoot at the fruiting level were measured using a CI-203 laser meter (CID, Inc., USA). The leaf area, length, width and thickness were determined two times during the vegetation (16 June and 29 July 1999, 29 May and 13 July 2000, 05 June and 06 August 2001).

The growth of plants was evaluated on the basis of index analysis, using the following indices: LAI (leaf area index) - the ratio of leaf area per plant to available land surface per plant $\left(\mathrm{cm}^{2} \cdot \mathrm{m}^{-2}\right)$, LAR (leaf area ratio) - ratio of leaf area to total plant fresh matter $\left(\mathrm{cm}^{2} \cdot \mathrm{g}^{-1}\right)$, LFR (leaf fruit ratio) - number of leaves per one fruit (No.), and LAFR (leaf area fruit ratio) - leaf area per one fruit $\left(\mathrm{m}^{2}\right)$.

Leaf samples were collected from the main shoot at three levels of plant profile: the main embranchment, fruiting, and flowering in the phase of intensive vegetation growth (01 July 1999, 07 July 2000, 01 July 2001). Dry matter was determined using a desiccator's method at $95-98^{\circ} \mathrm{C}$. Leaf pigments were determined with colorimetric method (Lichtenthaler \& Wellburn 1983). Pigments were extracted with $80 \%$ acetone and absorbance at $646 \mathrm{~nm}$ (chlorophyll 
a), 663 (chlorophyll b), and $470 \mathrm{~nm}$ (carotenoids) was measured with a Specol 11 spectrophotometer (Carl Zeiss, Jena). The anthron method (Hansen \& Moller 1975) was used to determine the reducing sugar and starch concentration while absorption was measured at $625 \mathrm{~nm}$ with a SP6-500 UV (Pye Unicam, USA) spectrophotometer.

Leaf samples for microscopic analysis of mesophyll tissues thickness were collected from the main shoot at three levels of plant profile: the main embranchment, fruiting, and flowering, at 8-9 a.m. on 5 July 1999. The leaves were preserved in a $2.5 \%$ solution of glutarate aldehyde at $0.1 \mathrm{~mol} \cdot \mathrm{dm}^{-3}$ phosphate buffer $\mathrm{pH} 7.2$ and then at $1 \%$ of osmium tetroxide at $0.1 \mathrm{~mol} \cdot \mathrm{dm}^{-3}$ phosphate buffer $\mathrm{pH} 7.2$ (Forssmann 1969). Sample dehydration was performed in ethanol and scaling at epon 8.2 (Luft 1961). $1 \mu \mathrm{m}$ sections were contrasted with the Azur II - methylene blue and examined in a light (Jenawal) and electron (Tesla BS 500) microscope for the thickness of the palisade and spongy mesophyll of the leaf blade.

Leaf samples for microscopic analysis of starch grains were collected from the main shoot at three levels of the plant profile: the main embranchment, fruiting, and flowering, at 7 p.m. on 6 July 2001. The samples were preserved by the above labeled method, additionally treated with $1 \%$ osmic acid, and contrasted with uranyl acetate and lead citrate (Venable \& Coggeshal 1965).

The results of plant growth and chemical analysis represent means from 3year experiment. Treatment effects were statistically evaluated by ANOVA, Newman-Keuls test at $\mathrm{P}=0.05$. Coefficients of simple correlation ( $\mathrm{r}$ ) were used to determine the association between PAR and chosen plant growth factors and chemical components of eggplant leaves.

\section{RESULTS}

\section{Photosynthetically active radiation (PAR) in plants profile}

The percentage of PAR transmitted to a corresponding level of plants profile in relation to that recorded at the upper surface of eggplant canopy is presented in Figure 1. The lowest PAR transmittance was observed in treatments pruned to two shoots with one fruit set at the level of main embranchment and fruiting. The best light conditions at the level of fruiting prevailed in the profile of plants pruned to one shoot with two fruit sets per node. At the level of flowering light conditions were the most beneficial and at this level PAR was differentiated in the smallest degree among the treatments.

Significant correlations were found between PAR level at the beginning of fruiting and leaf thickness $(\mathrm{r}=0.960)$, and the level of chlorophyll a $(\mathrm{r}=0.896)$, chlorophyll $\mathrm{b}(\mathrm{r}=0.778)$, and reducing sugar $(\mathrm{r}=0.714)$. Simultaneously, PAR was inversely proportional to palisade and spongy parenchyma thickness $(r=-0.631$ and $r=-0.533$, respectively $)$. 


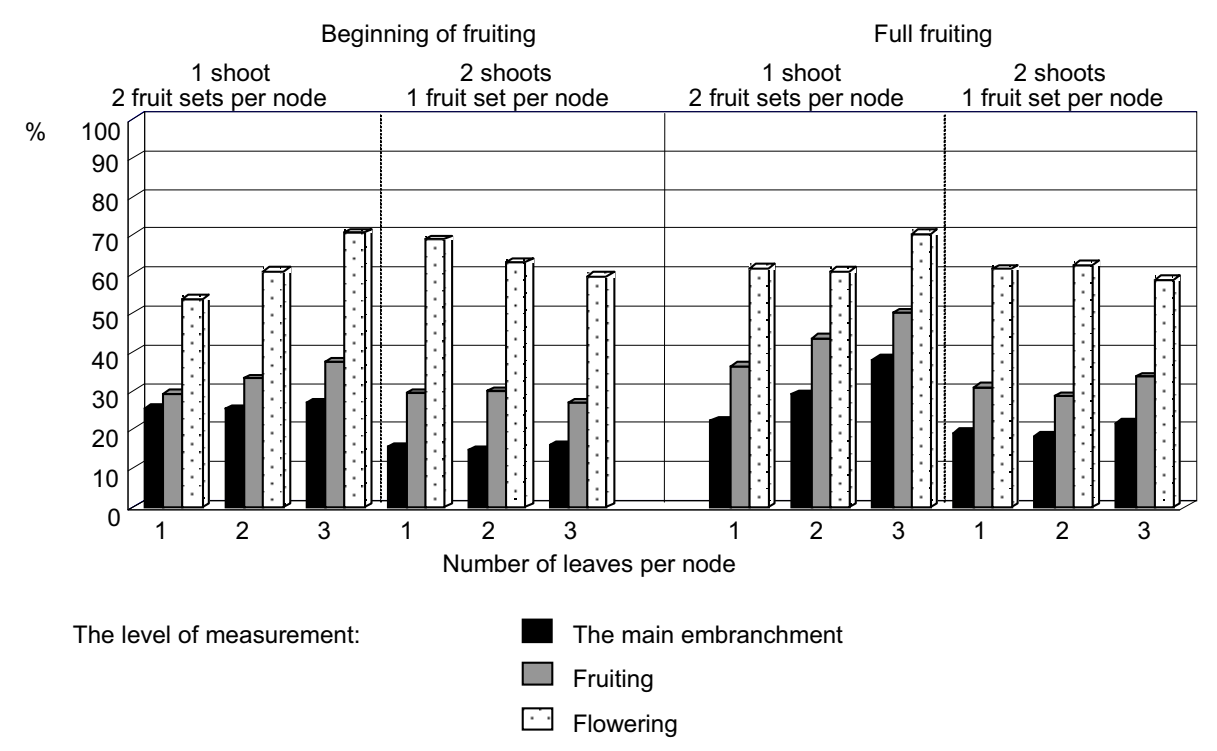

Fig. 1. Photosynthetically active radiation (PAR) in percentages of radiation measured above plants $(100 \%)$

\section{Plant growth analysis}

Pruning treatments resulted in differences in single leaf area of eggplant without influence on its thickness (Table 1). At the beginning of fruiting, plants pruned to one shoot were characterized by greater single leaf area than to two shoots. Greatest leaf blades were shaped by plants pruned to two fruit sets and one leaf in every node as opposed to plants pruned to one fruit set and two leaves on two shoots. At full fruiting the mean leaf area was about $23 \%$ smaller in comparison to the beginning of fruiting, without statistical differences between the treatments. The significant differences in leaf blades shape between the treatments were found (Table 2). At the beginning of fruiting the longest and widest leaves were found in plants pruned to one shoot, with two fruit sets and one leaf in every node. At full fruiting the mean length and width of leaves were smaller by 15 and $21 \%$ respectively.

Eggplant pruning did not affect leaf blade thickness but induced different development of leaf tissues. Pruning treatments resulted in different mesophyll tissue development (Table 3). Thicker layer of palisade mesophyll was found at the main embranchment in plants pruned to two shoots with one fruit set and three leaves in every node. The mentioned treatment was characterized by the thinnest layer of both mesophyll tissues at the level of flowering. Plants pruned to one shoot with two fruit sets and one or two leaves in every node formed the thickest layer of palisade and spongy mesophyll at the level of fruiting. The same phenomenon was observed in the case of plants pruned to two shoots, with one fruit set and two leaves in every node. In the case of the mentioned treatments the thickness of palisade tissue was between 216.1-221.4 $\mu \mathrm{m}$, and spongy tissue between 199.1-242.1 $\mu \mathrm{m}$. 
Table 1. The area $\left(\mathrm{cm}^{2}\right)$ and thickness $(\mu \mathrm{m})$ of the single leaf blade depending on pruning method, means for 1999-2001

\begin{tabular}{cccccc}
\hline \multirow{2}{*}{ Pruning method } & \multicolumn{2}{c}{ Leaf area } & \multicolumn{2}{c}{ Leaf thickness } \\
\cline { 2 - 6 } 1 shoot & $\begin{array}{l}\text { Beginning } \\
\text { of fruiting }\end{array}$ & Full fruiting & $\begin{array}{l}\text { Beginning } \\
\text { of fruiting }\end{array}$ & Full fruiting \\
\hline $\begin{array}{r}2 \text { fruit sets } \\
+1 \text { leaf } \\
+2 \text { leaves }\end{array}$ & $636 \mathrm{c}$ & 456 n.s. & 298 n.s. & 302 n.s. \\
\hline \begin{tabular}{l}
\hline fruit sets \\
+3 leaves
\end{tabular} & 614 bc & 432 n.s. & 299 n.s. & 304 n.s. \\
\hline $\begin{array}{l}1 \text { fruit set } \\
+1 \text { leaf }\end{array}$ & 565 ab & 461 n.s. & 296 n.s. & 318 n.s. \\
\hline $\begin{array}{l}1 \text { fruit set } \\
+2 \text { leaves }\end{array}$ & $529 \mathrm{a}$ & 434 n.s. & 292 n.s. & 323 n.s. \\
\hline $\begin{array}{l}1 \text { fruit set } \\
+3 \text { leaves }\end{array}$ & $569 \mathrm{ab}$ & 435 n.s. & 297 n.s. & 312 n.s. \\
\hline
\end{tabular}

Note: Values in columns marked with the same letter do not differ significantly at $\mathrm{P}=0.05$

Table 2. The length and width $(\mathrm{cm})$ of leaf blades depending on pruning method, means for 1999-2001

\begin{tabular}{|c|c|c|c|c|c|}
\hline \multirow{2}{*}{\multicolumn{2}{|c|}{ Pruning method }} & \multicolumn{2}{|c|}{ Leaf length } & \multicolumn{2}{|c|}{ Leaf width } \\
\hline & & $\begin{array}{l}\text { Beginning } \\
\text { of fruiting }\end{array}$ & Full fruiting & $\begin{array}{l}\text { Beginning } \\
\text { of fruiting }\end{array}$ & Full fruiting \\
\hline \multirow{3}{*}{1 shoot } & $\begin{array}{l}2 \text { fruit sets } \\
+1 \text { leaf }\end{array}$ & $32.1 \mathrm{c}$ & $27.8 \mathrm{abc}$ & $26.7 \mathrm{c}$ & 22.3 n.s. \\
\hline & $\begin{array}{l}2 \text { fruit sets } \\
+2 \text { leaves }\end{array}$ & $30.8 \mathrm{bc}$ & $29.3 \mathrm{c}$ & $26.5 \mathrm{bc}$ & 22.6 n.s. \\
\hline & $\begin{array}{l}2 \text { fruit sets } \\
+3 \text { leaves } \\
\end{array}$ & $31.2 \mathrm{c}$ & $28.2 \mathrm{abc}$ & $26.0 \mathrm{abc}$ & 22.8 n.s. \\
\hline \multirow{3}{*}{2 shoots } & $\begin{array}{l}1 \text { fruit set } \\
+1 \text { leaf }\end{array}$ & $29.2 \mathrm{ab}$ & $28.9 \mathrm{bc}$ & $26.0 \mathrm{abc}$ & 22.1 n.s. \\
\hline & $\begin{array}{l}1 \text { fruit set } \\
+2 \text { leaves }\end{array}$ & $27.3 \mathrm{a}$ & $27.6 \mathrm{ab}$ & $25.0 \mathrm{a}$ & 21.9 n.s. \\
\hline & $\begin{array}{l}1 \text { fruit set } \\
+3 \text { leaves }\end{array}$ & $31.0 \mathrm{bc}$ & $26.7 \mathrm{a}$ & $25.4 \mathrm{ab}$ & 22.3 n.s. \\
\hline
\end{tabular}

Note: see Table 1 
Table 3. Thickness of the parenchymas in eggplant leaves $(\mu \mathrm{m})$ depending on pruning method, means for 1999-2001

\begin{tabular}{|c|c|c|c|c|c|}
\hline \multicolumn{2}{|c|}{ Pruning method } & $\begin{array}{l}\text { Level of } \\
\text { sampling }\end{array}$ & $\begin{array}{l}\text { Palisade pa- } \\
\text { renchyma }(\mathrm{P})\end{array}$ & $\begin{array}{c}\text { Spongy } \\
\text { parenchyma } \\
(\mathrm{S})\end{array}$ & $\mathrm{P}+\mathrm{S}$ \\
\hline \multirow{9}{*}{1 shoot } & \multirow{3}{*}{$\begin{array}{l}2 \text { fruit sets } \\
+1 \text { leaf }\end{array}$} & $\mathrm{I}$ & $156 \mathrm{~cd}$ & 174 abcde & $330 \mathrm{~cd}$ \\
\hline & & II & $218 \mathrm{fg}$ & 199 defgh & $417 \mathrm{fg}$ \\
\hline & & III & $171 \mathrm{~d}$ & $163 \mathrm{abc}$ & $334 \mathrm{de}$ \\
\hline & \multirow{3}{*}{$\begin{array}{l}2 \text { fruit sets } \\
+2 \text { leaves }\end{array}$} & $\mathrm{I}$ & $167 \mathrm{~cd}$ & $151 \mathrm{a}$ & $318 \mathrm{bcd}$ \\
\hline & & II & $221 \mathrm{fg}$ & 200 efgh & $421 \mathrm{fgh}$ \\
\hline & & III & $137 \mathrm{ab}$ & $151 \mathrm{a}$ & $288 \mathrm{ab}$ \\
\hline & \multirow{3}{*}{$\begin{array}{l}2 \text { fruit sets } \\
+3 \text { leaves }\end{array}$} & I & $225 \mathrm{fg}$ & 205 fghi & $430 \mathrm{fgh}$ \\
\hline & & II & $124 \mathrm{a}$ & $154 \mathrm{ab}$ & $279 \mathrm{a}$ \\
\hline & & III & $128 \mathrm{a}$ & 170 abcd & $298 \mathrm{abc}$ \\
\hline \multirow{9}{*}{2 shoots } & \multirow{3}{*}{$\begin{array}{l}1 \text { fruit set } \\
+1 \text { leaf }\end{array}$} & $\mathrm{I}$ & $229 \mathrm{fg}$ & 211 ghi & 440 ghi \\
\hline & & II & $191 \mathrm{e}$ & $218 \mathrm{hij}$ & $409 \mathrm{f}$ \\
\hline & & III & $150 \mathrm{bc}$ & 188 cdefgh & $338 \mathrm{de}$ \\
\hline & \multirow{3}{*}{$\begin{array}{l}1 \text { fruit set } \\
+2 \text { leaves }\end{array}$} & $\mathrm{I}$ & $174 \mathrm{de}$ & 184 bcdefg & $358 \mathrm{e}$ \\
\hline & & II & $216 \mathrm{f}$ & $242 \mathrm{j}$ & $458 \mathrm{hi}$ \\
\hline & & III & $124 \mathrm{a}$ & 177 abcdef & $301 \mathrm{a}$ \\
\hline & \multirow{3}{*}{$\begin{array}{l}1 \text { fruit set } \\
+3 \text { leaves }\end{array}$} & $\mathrm{I}$ & $236 \mathrm{~g}$ & $230 \mathrm{ij}$ & $466 \mathrm{i}$ \\
\hline & & II & $174 \mathrm{de}$ & 192 cdefgh & $357 \mathrm{e}$ \\
\hline & & III & $126 \mathrm{a}$ & $152 \mathrm{a}$ & $278 \mathrm{a}$ \\
\hline
\end{tabular}

Note : see Table 1

The level of sampling: I - main embranchment, II - fruiting, III - flowering

Table 4. Plant growth indices, means for 1999-2001

\begin{tabular}{cccccc}
\hline Pruning method & $\begin{array}{c}\text { Leaf area } \\
\text { index (LAI) }\end{array}$ & $\begin{array}{c}\text { Leaf area } \\
\text { ratio (LAR) }\end{array}$ & $\begin{array}{c}\text { Leaf fruit } \\
\text { ratio (LFR) }\end{array}$ & $\begin{array}{c}\text { Leaf area } \\
\text { fruit ratio } \\
\text { (LAFR) }\end{array}$ \\
\hline $\begin{array}{l}2 \text { fruit sets } \\
+1 \text { leaf }\end{array}$ & $4.77 \mathrm{ab}$ & 1.38 n.s. & 5.07 n.s. & 0.20 n.s. \\
\hline $\begin{array}{l}2 \text { fruit sets } \\
+2 \text { leaves }\end{array}$ & $2.86 \mathrm{a}$ & 1.25 n.s. & 4.35 n.s. & 0.13 n.s. \\
\hline $\begin{array}{l}\text { 2 fruit sets } \\
+3 \text { leaves }\end{array}$ & $5.12 \mathrm{~b}$ & 1.57 n.s. & 4.87 n.s. & 0.21 n.s. \\
\hline $\begin{array}{l}1 \text { fruit set } \\
+1 \text { leaf }\end{array}$ & $4.17 \mathrm{ab}$ & 1.10 n.s. & 3.69 n.s. & 0.14 n.s. \\
\hline $\begin{array}{l}1 \text { fruit set } \\
+2 \text { leaves }\end{array}$ & $3.92 \mathrm{ab}$ & 1.15 n.s. & 3.83 n.s. & 0.14 n.s. \\
\hline $\begin{array}{l}1 \text { fruit set } \\
+3 \text { leaves }\end{array}$ & $4.93 \mathrm{~b}$ & 1.31 n.s. & 5.14 n.s. & 0.18 n.s. \\
\hline
\end{tabular}

Note: see Table 1

Plant growth indices reflected the influence of pruning on plant development only to a small degree (Table 4). There were no differences between 
treatments in the values of LAR, LFR, and LAFR indices, with the means of $1.29,4.49$, and 0.17 , respectively. The greatest diversity of LAI was found in plants pruned to one shoot.

Dry matter content in leaves was differentiated not among the treatments but particularly among the levels of sampling. The leaves from the main embranchment were characterized by the lowest dry matter content (Table 5). Plants pruned to one shoot contained more starch in leaves as compared to two shoots, particularly in treatments with three leaves in every node. In the case of plants with one shoot, the level of starch was greater in leaves from the level of fruiting or flowering, formed in the best light conditions. The reducing sugar level was similar to the level of starch. The filling of chloroplasts with starch in leaves of eggplant from exemplary treatments is presented in Figure 2.

Table 5. The content of dry matter, starch, and reduced sugar in eggplant leaves depending on pruning method, means for 1999-2001

\begin{tabular}{|c|c|c|c|c|c|}
\hline \multicolumn{2}{|c|}{ Pruning method } & $\begin{array}{c}\text { The } \\
\text { level of } \\
\text { sampling }\end{array}$ & $\begin{array}{c}\text { Dry matter } \\
(\%)\end{array}$ & $\begin{array}{c}\text { Starch } \\
\left(\mathrm{mg} \cdot \mathrm{g}^{-1} \mathrm{~d} \cdot \mathrm{m} .\right)\end{array}$ & $\begin{array}{l}\text { Reduced sugar } \\
\left(\mathrm{mg} \cdot \mathrm{g}^{-1} \mathrm{~d} . \mathrm{m} .\right)\end{array}$ \\
\hline \multirow{9}{*}{1 shoot } & \multirow{3}{*}{$\begin{array}{l}2 \text { fruit sets } \\
+1 \text { leaf }\end{array}$} & $\mathrm{I}$ & $12.0 \mathrm{~b}$ & $28.8 \mathrm{cde}$ & $23.5 \mathrm{ab}$ \\
\hline & & II & $15.9 \mathrm{e}$ & 29.1 cde & $32.2 \mathrm{efgh}$ \\
\hline & & III & $17.1 \mathrm{hi}$ & $28.3 \mathrm{~cd}$ & $28.5 \mathrm{cde}$ \\
\hline & \multirow{3}{*}{$\begin{array}{l}2 \text { fruit sets } \\
+2 \text { leaves }\end{array}$} & I & $12.4 \mathrm{bc}$ & $26.9 \mathrm{~cd}$ & $26.9 \mathrm{bcd}$ \\
\hline & & II & $16.1 \mathrm{e}$ & $32.6 \mathrm{efg}$ & $32.2 \mathrm{efgh}$ \\
\hline & & III & $17.4 \mathrm{i}$ & 30.7 defg & 30.0 def \\
\hline & \multirow{3}{*}{$\begin{array}{l}2 \text { fruit sets } \\
+3 \text { leaves }\end{array}$} & $\mathrm{I}$ & $11.4 \mathrm{a}$ & $29.8 \mathrm{cdef}$ & $28.8 \mathrm{cdef}$ \\
\hline & & II & $14.3 \mathrm{~d}$ & $33.7 \mathrm{fg}$ & $32.5 \mathrm{efgh}$ \\
\hline & & III & $17.4 \mathrm{i}$ & $34.3 \mathrm{~g}$ & $35.8 \mathrm{~h}$ \\
\hline \multirow{9}{*}{2 shoots } & \multirow{3}{*}{$\begin{array}{l}1 \text { fruit set } \\
+1 \text { leaf }\end{array}$} & $\mathrm{I}$ & $11.9 \mathrm{~b}$ & $28.9 \mathrm{cde}$ & $34.7 \mathrm{gh}$ \\
\hline & & II & $14.3 \mathrm{~d}$ & $33.5 \mathrm{fg}$ & $32.8 \mathrm{fgh}$ \\
\hline & & III & $16.6 \mathrm{gh}$ & $28.1 \mathrm{~cd}$ & $30.7 \mathrm{defg}$ \\
\hline & \multirow{3}{*}{$\begin{array}{l}1 \text { fruit set } \\
+2 \text { leaves }\end{array}$} & I & $12.7 \mathrm{c}$ & 30.6 defg & 30.6 defg \\
\hline & & II & $14.4 \mathrm{~d}$ & $28.5 \mathrm{cde}$ & $28.6 \mathrm{cdef}$ \\
\hline & & III & $16.6 \mathrm{fg}$ & $25.8 \mathrm{bc}$ & $25.2 \mathrm{abc}$ \\
\hline & \multirow{3}{*}{$\begin{array}{l}1 \text { fruit set } \\
+3 \text { leaves }\end{array}$} & $\mathrm{I}$ & $12.1 \mathrm{~b}$ & $26.7 \mathrm{~cd}$ & $22.9 \mathrm{ab}$ \\
\hline & & II & $16.1 \mathrm{ef}$ & $22.1 \mathrm{ab}$ & $25.7 \mathrm{abc}$ \\
\hline & & III & $16.4 \mathrm{efg}$ & $19.0 \mathrm{a}$ & $21.5 \mathrm{a}$ \\
\hline
\end{tabular}

Note: see Table 3

Pigments content depended mainly on the level of sampling in the depth of eggplant profile (Table 6). At the level of fruiting chlorophylls content was on average $7.1 \%$ lower and at the main embranchment - $24.9 \%$ lower. Carotenoids content was $8 \%$ and $22 \%$ lower at respective levels. The way of pruning had insignificant effect on the pigments content in eggplant leaves. The leaves of plants pruned to one shoot contained on average $2.00 \mathrm{mg} \cdot \mathrm{g}^{-1} \mathrm{f} . \mathrm{m}$. of chlorophyll a and leaves from plants pruned to two shoots $1.90 \mathrm{mg} \cdot \mathrm{g}^{-1} \mathrm{f} . \mathrm{m}$. of chlorophyll a. 

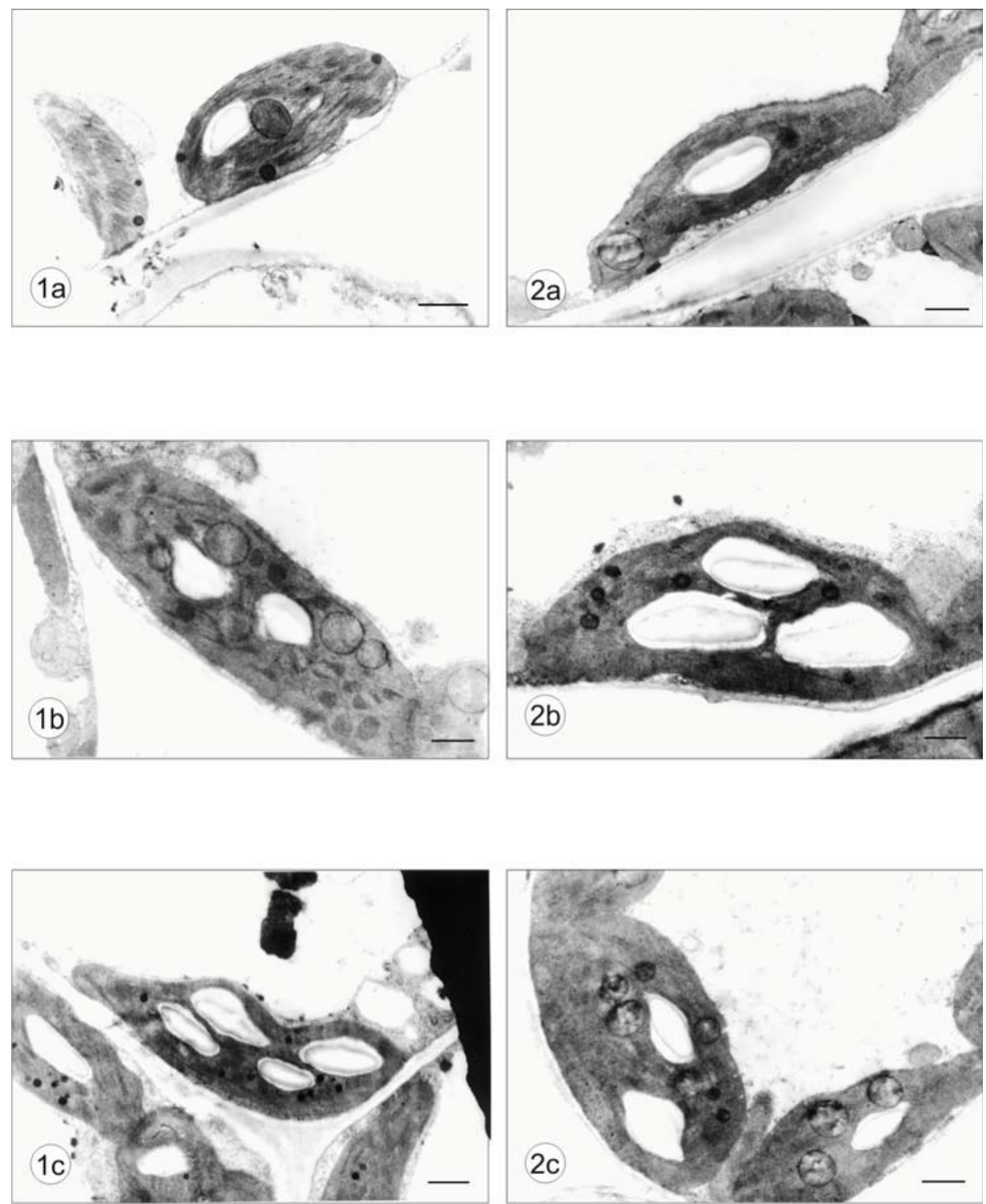

Fig. 2. The filling of chloroplasts with starch in leaves of eggplant pruned to two shoots and 1 fruit set and 1 leaf in every node (1a-1c) or 1 fruit set and 3 leaves in every node (2a-2c). The level of sampling: a-main embranchment, b-fruiting, c-flowering $(\mathrm{bar}=100 \mathrm{~nm}$ ) 
Table 6. The content of pigments in eggplant leaves depending on pruning method, means for 1999-2001

\begin{tabular}{|c|c|c|c|c|c|}
\hline \multicolumn{2}{|c|}{ Pruning method } & $\begin{array}{c}\text { The } \\
\text { level of } \\
\text { sampling }\end{array}$ & $\begin{array}{l}\text { Chlorophyll a } \\
\text { (mg } \cdot \mathrm{g}^{-1} \text { f.m.) }\end{array}$ & $\begin{array}{c}\text { Chlorophyll b } \\
\text { (mg } \cdot \mathrm{g}^{-1} \text { f.m.) }\end{array}$ & $\begin{array}{l}\text { Carotenoids } \\
\left(\mathrm{mg} \cdot \mathrm{g}^{-1} \text { f.m.) }\right.\end{array}$ \\
\hline \multirow{9}{*}{1 shoot } & \multirow{3}{*}{$\begin{array}{l}2 \text { fruit sets } \\
+1 \text { leaf }\end{array}$} & I & $1.23 \mathrm{ab}$ & $0.53 \mathrm{abc}$ & $0.40 \mathrm{a}$ \\
\hline & & II & $1.53 \mathrm{def}$ & $0.60 \mathrm{def}$ & $0.50 \mathrm{cde}$ \\
\hline & & III & $1.63 \mathrm{fghi}$ & $0.63 \mathrm{efg}$ & $0.53 \mathrm{de}$ \\
\hline & \multirow{3}{*}{$\begin{array}{l}2 \text { fruit sets } \\
+2 \text { leaves }\end{array}$} & I & $1.23 \mathrm{ab}$ & $0.53 \mathrm{abc}$ & $0.45 \mathrm{abc}$ \\
\hline & & II & 1.60 fghi & $0.60 \mathrm{def}$ & $0.53 \mathrm{de}$ \\
\hline & & III & $1.68 \mathrm{ghi}$ & $0.60 \mathrm{def}$ & $0.48 \mathrm{bcd}$ \\
\hline & \multirow{3}{*}{$\begin{array}{l}2 \text { fruit sets } \\
+3 \text { leaves }\end{array}$} & I & $1.15 \mathrm{a}$ & $0.55 \mathrm{bcd}$ & $0.43 \mathrm{ab}$ \\
\hline & & II & $1.43 \mathrm{~cd}$ & 0.56 cde & 0.50 cde \\
\hline & & III & $1.73 \mathrm{i}$ & $0.68 \mathrm{gh}$ & $0.63 \mathrm{f}$ \\
\hline \multirow{9}{*}{2 shoots } & \multirow{3}{*}{$\begin{array}{l}1 \text { fruit set } \\
+1 \text { leaf }\end{array}$} & I & $1.15 \mathrm{a}$ & $0.50 \mathrm{ab}$ & $0.40 \mathrm{a}$ \\
\hline & & II & $1.55 \mathrm{defg}$ & $0.53 \mathrm{abc}$ & 0.50 cde \\
\hline & & III & $1.58 \mathrm{efgh}$ & $0.58 \mathrm{cde}$ & $0.50 \mathrm{cde}$ \\
\hline & \multirow{3}{*}{$\begin{array}{l}1 \text { fruit set } \\
+2 \text { leaves }\end{array}$} & I & $1.18 \mathrm{a}$ & $0.48 \mathrm{a}$ & $0.40 \mathrm{a}$ \\
\hline & & II & $1.35 \mathrm{bc}$ & $0.60 \mathrm{def}$ & $0.50 \mathrm{cde}$ \\
\hline & & III & $1.70 \mathrm{hi}$ & $0.70 \mathrm{~h}$ & $0.55 \mathrm{e}$ \\
\hline & \multirow{3}{*}{$\begin{array}{l}1 \text { fruit set } \\
+3 \text { leaves }\end{array}$} & $\mathrm{I}$ & $1.18 \mathrm{a}$ & $0.50 \mathrm{ab}$ & $0.43 \mathrm{ab}$ \\
\hline & & II & $1.45 \mathrm{cde}$ & $0.63 \mathrm{efg}$ & $0.48 \mathrm{bcd}$ \\
\hline & & III & $1.68 \mathrm{ghi}$ & $0.65 \mathrm{fgh}$ & $0.55 \mathrm{e}$ \\
\hline
\end{tabular}

Note: see Table 3

\section{DISCUSSION}

Plant performance depends mainly on the size and characteristics of photosynthetically active organs which are controlled by growing conditions and techniques (Leonardi \& Giuffrida 1999). The energy of solar radiation, mainly in PAR range, absorbed by plants is used in photosynthesis (Czarnowski 1995). The level of PAR radiation recorded at different parts of eggplant profile depended on the way of pruning. The present results showed that more PAR radiation gets at the lower levels of plants pruned to one shoot in comparison to two shoots due to mutual shading of leaves as a result of plants topographic differentiation. Ambroszczyk \& Cebula (2003) determined that intensive pruning had a positive effect on irradiation on PAR range in plant profile. Czarnowski \& Cebula $(1998,1999)$ found significant correlation between the PAR transmittance and the leaf area index (LAI) during the vegetative season of sweet pepper and eggplant. Rosati \& Dejong (2003) demonstrated that both net and gross daily photosynthesis of leaves were linearly related to daily incident PAR exposure of individual leaves of eggplant which implies constant photosynthetic radiation use efficiency over a day throughout the canopy.

The evaluation of the basic traits of leaf blade development showed important changes in the leaf morphology and anatomy due to different severity of pruning. The first noticeable effect of pruning was differentiation in leaf area. 
Greater leaf area was noticed in plants pruned to one shoot. At full fruiting the leaf area was smaller, without differences between treatments. The results showed the balancing ability of eggplant which reveals in the increase of the area of particular leaves consequently of decrease of leaf number per plant. Similar results were obtained by Cebula (1996) and Cebula \& Ambroszczyk (2000) in eggplant and Cebula et al. (1998) in sweet pepper. Heuvelink \& Marcelis (1996) found that the area of individual leaves of pepper and tomato was hardly influenced by fruit or leaf pruning, but increased with increasing light intensity, decreasing plant density or the removal of every other truss. Increased assimilate supply resulted in an increase in dry matter of individual leaves and a decrease in specific leaf area. Cebula \& Kalisz (2001) stated a very distinct tendency in the development of single leaf area and thickness and the length and width of leaf blades, proportional to the degree of leaves and fruit sets removal in sweet pepper.

Pruning treatments resulted in different thickness of mesophyll tissue, without influence on the thickness of whole leaf blade. Thickest spongy and palisade mesophyll was found in the leaves from the level of first embranchment and the level of fruiting. The leaves of plants pruned to two shoots had thicker mesophyll tissue at the level of first embranchment as the result of shadowing. The increase of palisade thickness was due to the elongation of the single layer of palisade tissue. Two layers of palisade parenchyma were detected only in the case of most shadowed leaves from plants pruned in the smallest degree. Amiard et al. (2005) studied the ability to regulate photosynthesis in response to the light environment in four species (pea, spinach, pumpkin, and Verbascum phoeniceum). Within each species total leaf thickness was significantly greater in leaves of plants grown under high light, as compared to those grown in low light. This increase in leaf thickness was due to significantly thicker palisade or spongy tissue or double of mesophyll layers.

The change of plant assimilation area, reflected by LAI was the direct effect of pruning. The greatest LAI values were found in treatments were three leaves were left in every node. Eggplant is characterized by high vegetative development so LAI values are high in comparison to other species, despite of pruning. In fruit vegetable crops, proportion between leaves and fruits is strongly connected with productivity and earliness of yielding. Indices described by the number and area of leaves per one fruit (LAR and LAFR) for eggplant were lower than those described by Cebula \& Kalisz (2001) for sweet pepper. The lack of differences between treatments in LAR, LFR, and LAFR indices reflected the fruits production by plants pruned with different methods. Ambroszczyk et al. (2007) described the eggplant yielding characteristics and fruits quality in conditions of present experiment. Authors pointed, that intensive plant pruning did not reduce the eggplant yielding and plants pruned more intensively produced more fruits of high quality.

Dry matter production and partitioning are important yield determinants for fruit vegetables. The hypothesis that dry matter partitioning is determined by the sink strength of the various organs have been proposed and validated for 
tomato (Heuvelink \& Bertin 1994) and cucumber (Marcelis 1994). In these species, a greater number of fruits was able to attract more assimilates but with decreasing efficiency. Such behaviour shows that fruits do not have absolute priority over assimilates from the vegetative organs. In present experiment leaf and fruit set pruning did not significantly affect the level of dry matter in eggplant leaves. The lower dry matter content in older leaves (from the level of main embranchment) was caused by decrease of photosynthetic activity. Murage et al. (1996) found a wide range of dry matter (12-29\%) in eggplant leaves. Starch synthesis is promoted when sucrose synthesis is restricted and in many plant species leaf starch serves as a transient sink to accommodate excess photosynthate that can not be converted to sucrose and exported (Paul \& Foyer 2001). In present experiment plants pruned more intensively (one shoot) contained more starch and reducing sugar in leaf cells. High assimilate supply was connected with better light conditions in plant profile at this way of pruning. Also leaves from the level of flowering were richest in products of assimilation. Microscopic analysis (Fig. 2) illustrated that at the upper levels of plant profile, chloroplasts changed its shape from fusiform to spherical as a result of the most intensive development of starch grains. Such starch accumulation in photosynthetically active tissues of leaf blade is observed when the synthesis of sugars far exceeds their export and utilization. Such a situation applied for treatments with the least intensive pruning (two shoots). Amiard et al. (2005) stated that growing in high light conditions resulted in greater accumulation of starch in cells of the upper palisade layer of the half of tested species: spinach and $V$. phoeniceum.

Pruning did not significantly affect the level of photosynthetic pigments in eggplant leaves. Leaves from upper levels were richer in chlorophylls and carotenoids than older leaves from lower levels. The experiments of Amiard et al. (2005) showed that foliar chlorophyll content was constant in pea and spinach grown under low or high light conditions. Mean chlorophyll content in eggplant leaves was similar to elaborated by Park et al. (1996) with the use of acetone extraction.

Heuvelink \& Marcelis (1996) found that pepper and tomato vegetative and generative growth can be manipulated by factors such as plant density, light level or pruning treatments, without influencing plant development rate. Earlier studies of Cebula (1996) demonstrated that eggplant had a compensative capacity for the development of leaf area and thickness as a result of leaves and fruit sets pruning. It is interesting that improvement of photosynthesis efficiency of intensely pruned eggplants was achieved by the increase of single leaf area and thickness of leaf tissues without the increase of the level of assimilative pigments per plant mass unit.

\section{CONCLUSIONS}

1. Photosynthetically active radiation in plant profile was reduced in a highest degree in slightly pruned eggplants. 
2. Chemical composition of leaves was dependent on the method of pruning only in the case of assimilation products, i.e. reducing sugar and starch.

3. Improvement of photosynthesis efficiency of intensively pruned eggplants was achieved by the increase of single leaf area and thickness of leaf mesophyll tissues without the increase of the level of assimilative pigments per plant mass unit.

\section{REFERENCES}

Ambroszczyk A.M., Cebula S. 2003. Pruning and productivity of eggplant (Solanum melongena L.) in glasshouse production. Acta Agr. Silv. Ser. Agr. 41: 71-81.

Ambroszczyk A.M., Cebula S., Sekara A. 2007. The effect of plant pruning on eggplant (Solanum melongena L.) yield and fruit quality in greenhouse cultivation. Hort. Environ. Biotechnol. 48(5): 277-285.

Amiard V., Mueh K.E., Demmig-Adams B., Ebbert V., Turgeon R., Adams W.W. 2005. Anatomical and photosynthetic acclimation to the light environment in species with different mechanisms of phloem loading. PNAS 102(36): 12968-12973.

Cebula S. 1996. Effect of plants pruning on the growth, yields, and fruit quality of two cultivars of eggplant (Solanum melongena L.) in greenhouse production. Acta Agr. Silv. Ser. Agr. 34: 1-11.

Cebula S., Ambroszczyk A.M. 2000. [The influence of plant defoliation on growth, yielding and fruit quality of eggplant grown in a greenhouse.] Roczn. AR Poznań 323: 233-237. [in Polish with English summary]

Cebula S., Kalisz A. 2001. The effect of side shoots pruning on the growth and fruiting of sweet pepper plants trained to one main shoot in greenhouse production. Veget. Crops Res. Bull. 54(1): 91-98.

Cebula S., Kalisz A., Kunicki E. 1998. Canopy formation of sweet pepper plants pruned to one main shoot in greenhouse production. Folia Hort. 10/2: 35-44.

Czarnowski M. 1995. Photosynthesis in green pepper fruits. Folia Hort. 7/1: 37-47.

Czarnowski M., Cebula S. 1996. Effect of leaf area index on the spectral transmittance of solar radiation in greenhouse cultivation of sweet pepper plants. Folia Hort. 8/1: 53-72.

Czarnowski M., Cebula S. 1998. Spectral properties of sweet pepper fruits. Folia Hort. 10/1: 39-51.

Czarnowski M., Cebula S. 1999. Spectral properties of cultivation, leaves, and fruits of the aubergine. Folia Hort. 11/1: 15-28.

Eşiyok D., Eser B. 1998. The effect of stem pruning on yield and earliness of greenhouse eggplants. In: Proc. 2 Sebze Tarimi Sempzyumu, Tokat: 130-134.

Forssmann W.G. 1969. A method for in vivo diffusion tracer studies combining perfusion fixation with intravenous tracer injection. Histochemie 20: 277-286.

Hansen J., Moller J. 1975. Percolation of starch and soluble carbohydrates from plant tissue for quantitative determination with anthrone. Anal. Biochem. 68: 89-94. [DOI: 10.1016/0003-2697(75)90682-X]

Heuvelink E., Bertin N. 1994. Dry matter partitioning in tomato crop: comparison of two simulation models. J. Hort. Sci. 69: 885-903.

Heuvelink E., Marcelis L.F.M. 1996. Influence of assimilate supply on leaf formation in sweet pepper and tomato. J. Hort. Sci. 71(3): 405-414.

Leonardi C., Giuffrida F. 1999. Changes in some traits of greenhouse eggplant leaves. Acta Hort. 491: 215-220. 
Lichtenthaler H.K., Wellburn A.R. 1983. Determinations of total carotenoids and chlorophylls $\mathrm{a}$ and $\mathrm{b}$ of leaf extracts by different solvents. Biochem. Soc. Trans. 603: 591-592.

Luft J.H. 1961. Improvements in epoxy resin embedding methods. J. Biophys. Biochem. Cytol. 9: 409-414.

Marcelis L.F.M. 1994. A simulation model for dry matter partitioning in cucumber. Ann. Bot. 74: 43-52.

Murage E.N., Noriko W., Masaharu M. 1996. Leaf chlorosis and carbon metabolism of eggplant in response to continuous light and carbon dioxide. Sci. Hort. 67(1-2): 27-37. [DOI: 10.1016/S0304-4238(96)00930-2]

Paksoy M., Akilli M. 1994. The effects of different prunings on the yield and quality of eggplant cultivars grown in the greenhouse conditions. Acta Hort. 366: 287-292.

Park J.M., Ro H.M., Kim Y.M., Seong K.C. 1996. Chlorophyll determination in horticultural crops using dimethyl sulphoxide. RDA J. Agric. Sci. 38(1): 553-557.

Paul M.J., Foyer C.H. 2001. Sink regulation of photosynthesis. J. Exp. Bot. 52, 360: 1383-1400.

Pessarakli M.M., Dris R. 2003. Effects of pruning and spacing on the yield and quality of eggplant. J. Food Agric. Environ. 1(2): 215-21.

Rosati A., Dejong T.M. 2003. Estimating photosynthetic radiation use efficiency using incident light and photosynthesis of individual leaves. Ann. Bot. 91: 869-877.

Venable J.H., Coggeshal R. 1965. A simplifies lead citrate stain for use in electron microscopy. J. Cell Biol. 25(2): 407-408.

\section{WPŁYW CIĘCIA ROŚLIN NA WARUNKI ŚWIETLNE \\ I ROZWÓJ WEGETATYWNY OBERŻYNY (SOLANUM MELONGENA L.) W UPRAWIE SZKLARNIOWEJ}

\section{Streszczenie}

Celem badań było określenie relacji pomiędzy metodą cięcia a wybranymi parametrami charakteryzującymi rozwój wegetatywny oberżyny. Badania prowadzono w latach 1999-2001 w Akademii Rolniczej w Krakowie. Obiektem badań była odmiana Tania $F_{1}$, uprawiana w szklarni ogrzewanej w terminie wiosenno-letnim. Zastosowano następujące metody cięcia roślin: na jeden pęd, pozostawiając w każdym węźle 2 zawiązki owoców i 1, 2 lub 3 liście oraz na dwa pędy, pozostawiając w każdym węźle 1 zawiązek i 1, 2 lub 3 liście. Intensywne cięcie polepszało warunki napromieniowania w profilu roślin. Wskaźnik pokrycia liściowego (LAI) zależał od metody cięcia roślin. Skład chemiczny liści był uzależniony od metody cięcia tylko w przypadku produktów asymilacji (cukry redukujące, skrobia). Poprawa wydajności fotosyntetycznej intensywnie ciętych roślin była następstwem zwiększenia powierzchni blaszki liściowej i grubości tkanek miękiszowych, natomiast poziom barwników fotosyntetycznie czynnych pozostawał bez zmian. 